\title{
A tribute to Menke (1970): Results of pollen analysis on the Pleistocene stratigraphy and the Pliocene-Pleistocene boundary in Schleswig-Holstein
}

\author{
Roberta Pini \\ CNR - Institute of Environmental Geology and Geoengineering (IGAG), Research Group on Vegetation, Climate and Human \\ Stratigraphy, Laboratory of Palynology and Palaeoecology, Piazza della Scienza 1, 20126 Milan, Italy
}

Correspondence: Roberta Pini (roberta.pini@igag.cnr.it)

Relevant dates: $\quad$ Received: 28 June 2021 - Revised: 1 September 2021 - Accepted: 30 October 2021 Published: 17 December 2021

How to cite: $\quad$ Pini, R.: A tribute to Menke (1970): Results of pollen analysis on the Pleistocene stratigraphy and the Pliocene-Pleistocene boundary in Schleswig-Holstein, E\&G Quaternary Sci. J., 70, 239-242, https://doi.org/10.5194/egqsj-70-239-2021, 2021.

Special issue statement. This article is part of a special issue published on the occasion of the 70th anniversary of $E \& G$ Quaternary Science Journal (EGQSJ). The special issue celebrates the journal's notable contribution to Quaternary research by revisiting selected milestone articles published in the long history of EGQSJ. The German Quaternary Association (DEUQUA) presents translations of the originals and critical appraisals of their impact in tandem anniversary issues of DEUQUASP and EGQSJ, respectively.

Original article: https://doi.org/10.3285/eg.21.1.01

Translation: https://doi.org/10.5194/deuquasp-3$87-2021$

\section{Introduction}

The Quaternary history of Europe has been strongly influenced by the waxing and waning of ice masses and sea level oscillations. Climate change drove the behaviour of both ice sheets and sea levels and shaped terrestrial environments as far as land morphology, plant cover, fauna occurrence and diversity, and human migrations and survival were concerned. A major effort undertaken in the 20th century dealt with the assessment and the critical inventory of Quaternary stratigraphic units. Scientists paid great attention to the way in which environments have changed through time and how this topic can be investigated in stratigraphic records using a proxy-based approach. Among proxies, a robust descriptor of past terrestrial environments and climate is pollen. Pollen is almost ubiquitous in the vast majority of marine and terrestrial stratigraphic archives; it has huge fossilization potential due to its tough outer layer (exine) and can often be identified to a high taxonomic level of detail. In Europe pollen analytical investigations have been largely used to recognize warm and cold phases; biostratigraphical (pollen) data have then been used as a basis for time-stratigraphic subdivision and correlations of Quaternary sequences (i.e. Zagwijn, 1985).

Burchard Menke was a prominent German palynologist based at the Geological Survey of Schleswig-Holstein (in German, Geologisches Landesamt Schleswig-Holstein). Trusting in the robustness of the palynological approach, he explored German deposits of the Pliocene to Holocene, to obtain their hidden environmental and climatic message. In Menke's (1970) paper, the author provided a significant overview of the Pleistocene stratigraphy of SchleswigHolstein and of the issues concerned. He published later papers adding more insights into the stratigraphic and the palaeoenvironmental context of the area during Pliocene and Quaternary times (Menke, 1975, 1976a; Stephan and 
Menke, 1993), but research has continued since. Revisiting Menke's (1970) paper after more than 50 years implies having a closer look at the current state of the art of the pollen stratigraphical frame of Schleswig-Holstein to check how far his statements are still valid or instead need a substantial reappraisal.

\section{Plio-Pleistocene pollen stratigraphy of} Schleswig-Holstein - where are we after Menke's (1970) critical inventory?

Research published in the past decades provides new elements of further knowledge on the Quaternary palaeogeographic and palaeoenvironmental history of SchleswigHolstein. I hereafter recall four of the issues raised in Menke's (1970) paper, aiming to put them in an up-to-date context.

1. "Only little information is available from SchleswigHolstein about the course of the Weichselian Pleniglacial. It seems that there are hardly any deposits suitable for radiocarbon dating" (Menke, 1970, page 9).

The application of luminescence dating techniques to sediments beyond the radiocarbon limit laid the foundation of the chronological frame of the Weichselian Pleniglacial in Schleswig-Holstein, the attribution of sedimentary bodies to distinct glacial advances and their correlation with adjacent areas. Evidence of an early Middle Weichselian glaciation, named the "Ellund Phase", were TL dated to between $59.4 \pm 8.9$ and $52.5 \pm 7.9 \mathrm{ka}$ (Marks et al., 1995) and later referred to OSL ages between $92 \pm 24$ and $61 \pm 16 \mathrm{ka}$ (Preusser, 1999). These ages, obtained in the early times of luminescence dating techniques and possibly in need of a revision with improved methodologies, are in agreement with those of the "Ristinge Glaciation" in Denmark (Houmark-Nielsen, 2007). The Ellund Phase was followed by a period of ca. $30 \mathrm{kyr}$ of persisting cold climate with some minor milder breaks. During the Upper Weichselian several glacial advances are testified to in the area (Brandenburg, Frankfurt, Pomeranian and Mecklenburg phases; Litt et al., 2007), related to the development of Baltic ice streams covering northern Mecklenburg and part of Schleswig-Holstein (Stephan, 2014). Issues concerning the reliability of early luminescence ages (Frank Preusser, personal communication, 2021) and the nature and extent of Upper Weichselian glacial advances (Stephan, 2014) require further analysis.

2. "In Eemian deposits the oldest zones are generally only weakly represented" (Menke, 1970, page 6).

Menke and Tynni (1984) investigated a $32 \mathrm{~m}$ thick lacustrine sequence from Rederstall (western Holstein) documenting the interval from the early Eemian to the second post-Eemian interstadial (Odderade). According to the authors, pollen spectra obtained from the basal centimetres of the core are dominated by Pinus and Betula, along with some reworked pre-Quaternary palynomorphs. As suggested by biostratigraphic data, a hiatus occurs immediately above these sediments, as highlighted by the lack of the beginning of the Corylus and Quercus curves, displaying in zone E IVa percent values of around $20 \%-30 \%$ and $10 \%-20 \%$, respectively. A continuous sequence then follows, documenting the complete remaining interglacial succession and the Early Weichselian stadials and interstadials.

3. "We are still poorly informed about the Pre-Elsterian Pleistocene in Central Europe" (Menke, 1970, page 11).

Stephan (2014) mentions the scarcity of Elsterian deposits in eastern Germany due to the fact that in most areas they were eroded by subsequent glacial advances and only limited bodies were preserved in depressions. According to Vinxs et al. (1997), besides an older till at the base of the Lieth sequence, glacial deposits had not yet reliably been attributed to pre-Elsterian time. Authors do not, however, exclude the possibility that northern Germany was reached by older glaciations, as actually testified to north of the Danish-German border by deposits attributed to an early Middle Pleistocene advance (Stephan, 2011).

4. What is the state of the art of correlation between the northern Germany and Dutch Early Pleistocene?

The Early Pleistocene Lieth sequence, recovered from a limestone pit, was investigated by Menke (1970, 1975) and correlated first with the Quaternary series of the Netherlands elaborated by Zagwijn (1960) and then with the Lower Rhine sequence by Urban (1978) (Stephan and Menke, 1993). In revising the stratigraphical terms adopted for glaciated areas in northern Germany, Litt et al. (2007) recall the monumental work done by Menke on cores and sections and recognize that the criteria for palaeoclimatic subdivision into cold and warm stages largely relies on palynology. According to these authors, most of the correlations proposed by Menke between northern Germany and the Dutch Early Pleistocene are valid. Moreover, the pollen records elaborated by Menke and colleagues during the late 1960s1970s later provided some Early Pleistocene stratotypes, such as the Kaltenhörn-Kaltzeit (Kaltenhörn Cold Stage), the Ekholt-Kaltzeit (Ekholt Cold Stage) and the Nordende-Warmzeit (Nordende Warm Stage).

According to Stephan (2014), the correlation of the Lieth sequence with the Dutch series is questionable in some parts. The main issues refer to the lack of a clear chronostratigraphic framework at Lieth (magnetostratigraphy failed because of a weak signal of magnetic grains in sands between 
organic beds) and to the limited continuity of the Dutch series, not yet found in complete superposition. Further elements of concern were addressed by Menke (1975) and later on recalled by Kemna and Westerhoff (2007); according to these authors, facies-related features of sedimentation hamper any robust correlation among the series.

\section{Final remarks}

Generations of students and scholars dealing with the Pleistocene pollen stratigraphy of northern Germany have undoubtedly come across Menke's (1970) paper. The paper presented a clear overview of the state of the art for SchleswigHolstein: most of the statements provided by the original author are still valid. Substantial reappraisals mostly depend on the following:

- The development and application of new dating techniques, not yet in use in the late 1960s-early 1970s, are now available. As mentioned by Wintle (2008), OSL dating techniques were developed in 1985; 1999 was a year of further development, with the set-up of procedures for fast bleaching of single aliquots of quartz and instrumental improvements. The application of OSL methods to Weichselian stratigraphies allowed for setting them into a chronological frame, well beyond the limits of the radiocarbon method in use at that time. However, many of the sections mentioned by Menke (1970) and following authors still deserve proper attention as far as their age attribution by OSL is concerned.

- The increased number of investigated sequences has improved the quantity and quality of the available information, essential for a robust reconstruction of the complex stratigraphic and palaeoenvironmental history of Schleswig-Holstein. Other sites will hopefully be investigated in the future, and they will undoubtedly increase the level of knowledge that has been reached up to the present day.

Finally, as a palynologist who was initially trained on the Early Pleistocene sequence of Leffe (northern Italy), let me express sincere, although posthumous, thanks to Menke for the compilation of an important photographic atlas (Menke, 1976b). This book contains almost 1000 microphotographs of pollen grains and spores that he identified in Pliocene to Early Pleistocene deposits. Palynologists often face difficulties in finding appropriate iconographic documentation of palynomorphs of that age; Menke's atlas is of great help in this regard, and it is highly recommended in all pollen labs.

Acknowledgements. Thanks are due to Frank Preusser and to Philipp Stojakowits for suggestions.
Financial support. The article processing charge was funded by the Quaternary scientific community, as represented by the host institution of EGQSJ, the German Quaternary Association (DEUQUA).

Review statement. This paper was edited by Frank Preusser and reviewed by Philipp Stojakowits.

\section{References}

Houmark-Nielsen, M.: Extent and age of Middle and Late Pleistocene glaciations and periglacial episodes in southern Jylland, Denmark, B. Geol. Soc. Denmark, 50, 9-35, https://doi.org/10.37570/bgsd-2007-55-02, 2007.

Kemna, H. A. and Westerhoff, W. E.: Remarks on the palynologybased chronostratigraphical subdivision of Pliocene terrestrial deposits in NW-Europe, Quatern. Int., 164-165, 184-196, https://doi.org/10.1016/j.quaint.2006.10.017, 2007.

Litt, T., Behre, K.-E., Meyer, K.-D., Stephan, H.-J., and Wansa, S.: Stratigraphische Begriffe für das Quartär des norddeutschen Vereisungsgebiete, E\&G Quaternary Sci. J., 56, 7-65, https://doi.org/10.23689/fidgeo-1278, 2007.

Marks, C., Piotrowski, J. A., Stephan, H.-J., Fedorowicz, S., and Byìutrym, J.: Thermoluminescence indications of the Middle Weichselian (Vistulian) Glaciation in northwest Germany, Meyniana, 18, 35-42, 1995.

Menke, B.: Ergebnisse der Pollenanalyse zur PleistozänStratigraphie und zur Pliozän-Pleistozän-Grenze in Schleswig-Holstein, E\&G Quaternary Sci. J., 21, 5-21, https://doi.org/10.3285/eg.21.1.01, 1970.

Menke, B.: Vegetationsgeschichte und Florenstratigraphie Nordwestdeutschlands im Pliozän und Frühquartär mit einem Beitrag zur Biostratigraphie des Weichselfrühglazials, Geol. Jb. Hannover, A26, 3-151, 1975.

Menke, B.: Neue Ergebnisse zur Stratigraphie und Landschaftsentwicklung im Jungpleistozän Westholsteins, E\&G Quaternary Sci. J. (formerly Eiszeitalter und Gegenwart), 27, 53-68, https://doi.org/10.23689/fidgeo-1666, 1976a.

Menke, B.: Pliozäne und ältestquartäre Sporen- und Pollenflora von Schleswig-Holstein, Geol. Jb., Hannover, A32, 3-127, 1976 b.

Menke, B. and Tynni, R.: Das Eeminterglazial und das Weichselfrühglazial von Rederstall/Dithmarschen und ihre Bedeutung für die mitteleuropäische Jungpleistozän-Gliederung, Geol. Jb., Hannover, A76, 3-120, 1984.

Preusser, F.: Lumineszenzdatierung fluviatiler Sedimente; Fallbeispiele aus der Schweiz und Norddeutschland, Kölner Forum für Geologie und Paläontologie, 3, 1-62, 1999.

Stephan, H.-J.: Geschiebestratigraphische Untersuchungen im Bereich der Stauchmoräne Kisdorfer Wohld, Südholstein und in ihrem Hinterland, Geschiebekunde aktuell. Sonderh., 9, 113124, 2011.

Stephan, H.-J.: Climato-stratigraphic subdivision of the Pleistocene in Schleswig-Holstein, Germany and adjoining areas, E\&G Quaternary Sci. J., 63, 3-18, https://doi.org/10.3285/eg.63.1.01, 2014. 
Stephan, H.-J. and Menke, B.: Das Pleistozän in SchleswigHolstein, Geologisches Landesamt Schleswig-Holstein, 3, 1962, 1993.

Urban, B.: Vegetationsgeschichtliche Untersuchungen zur Gliederung des Altquartär der Niederrheinischen Bucht, Sonderveröffentlichungen des geologischen Instituts der Universität Köln, Köln, 34, 1-165,, 1978.

Vinxs, R., Grube, A. T., and Grube, F.: Lithologie, Geschiebeführung, und Geochemie eines Prä-Elster I-Tills von Lieth bei Elmshorn, Leipziger Geowissenschaften, Leipzig, 5, 83-103, 1997.
Wintle, A. G.: Fifty years of luminescence dating, Archaeometry, 50, 276-312, https://doi.org/10.1111/j.1475-4754.2008.00392.x, 2008.

Zagwijn, W. H.: Aspects of the Pliocene and early Pleistocene vegetation in the Netherlands, Mededelingen van de Geologische Stichting, Ser. C-III-1, 1-78, 1960.

Zagwijn W. H.: An outline of the Quaternary stratigraphy of the Netherlands, Geol. Mijnbouw, 64, 17-24, 1985. 